This PDF is a selection from a published volume from the National Bureau of Economic Research

Volume Title: Governance, Regulation, and Privatization in the Asia-Pacific Region, NBER East Asia Seminar on Economics, Volume 12

Volume Author/Editor: Takatoshi Ito and Anne O. Krueger, editors

Volume Publisher: University of Chicago Press

Volume ISBN: 0-226-38679-1

Volume URL: http://www.nber.org/books/ito_04-1

Conference Date: June 28-30, 2001

Publication Date: January 2004

Title: Recent Developments in the Public-Enterprise Sector of Korea

Author: Il Chong Nam

URL: http://www.nber.org/chapters/c10186 


\title{
Recent Developments in the Public-Enterprise Sector of Korea
}

\author{
Il Chong Nam
}

\subsection{Introduction}

The government has always been the dominant figure in the corporate landscape of Korea. This is not surprising, considering that Korea has a relatively short history of capitalism and that the government played a decisive role in the fast industrialization process that began in the 1960s. An important aspect of the economic development strategy of the successive administrations was the creation of large firms in modern industries that realize economies of scale and scope. Many large commercial Korean firms were established by the chaebol system, which crucially depended on the government's intervention in the financial market. Following the heavy and chemical industry drive of the mid-1970s, the automobile, shipbuilding, electronics, chemical, and oil refinery industries, as well as a host of others (including construction), were erected in this manner. ${ }^{1}$

The government's involvement has been more direct in the remaining industries that require large amounts of capital to start and maintain the business. The government owned and operated all of the major network industries, including telephony, postal services, electricity, gas, water, and rail transportation. It also owned and operated other large firms in manufacturing industries such as the tobacco and steel industries. All of these industries began virtually as government monopolies. The government also owned and operated monopolistic suppliers in minting, textbook publish-

Il Chong Nam is professor at the Korea Development Institute School of Public Policy and Management.

1. For a discussion on the chaebol system and industrial policies of past governments, see Nam, Kang, and Kim (2001) and Nam et al. (2001). 
ing, and several other industries whose main customer was the government itself. In addition, the government owned or invested in a score of firms in competitive industries such as newspapers, venture capital, coal mining, and chemicals. Furthermore, some bankrupt private firms were acquired by public enterprises and became public enterprises themselves. Finally, the government controlled and partly owned much of the financial sector for a long period before it nationalized much of the industry in the aftermath of the recent economic crisis.

The above-listed commercial businesses owned and controlled by the government took several different legal forms: government agencies, public corporations, and gongdan. ${ }^{2}$ For instance, rail transportation has been operating as a government agency within the transportation department, while telecommunications was transformed from a similar government agency into a public corporation. However, almost all of the commercial businesses owned and controlled by the government were perceived mainly as policy instruments rather than money-making firms, regardless of the form they took.

One consequence of such a command-and-control approach was the lack of separation among public enterprises' conflicting objectives. Policy objectives were generally not clearly separated from commercial goals. For network industries, separation among industrial policies, regulatory functions, and commercial operation was generally absent. Thus, the line ministry was charged with regulatory power on the one hand and the authority to make key business decisions for the monopolistic supplier under its control on the other. ${ }^{3}$ Further, it pursued a wide range of industrial policy objectives that were often in conflict with the other two objectives.

Although no rigorous empirical analysis has been conducted, it is widely believed that most of the public enterprises had serious problems in managerial efficiency due to conflicting goals and absence of clear accountability for various cost-inducing activities. Casual observation and scattered pieces of information all suggest that there were serious irregularities within most public enterprises. ${ }^{4}$ Scandals involving the procurement practices of public enterprises were not infrequent. Decisions on hiring, appointment of employees to various positions, promotions, and rewards

2. A gongdan is a nonprofit public foundation based on public laws.

3. The line ministry of a public enterprise is the ministry that is in charge of the industry to which the public enterprise belongs as well as policies relevant to the industry. Every public enterprise has its line ministry. The line ministry of a public enterprise has a wide range of authority over the relevant industry, including policy development, regulation of firms in the industry, and the control of the public enterprise.

4. It is interesting to note that while it is hard for anyone familiar with public enterprises to deny that they were inefficient, it is also hard to establish that large private firms were more efficient than public enterprises. Comparison of various indices on the financial performance of public enterprises and large private firms generally indicates that the latter fared worse. In fact, more than one-third of large chaebol firms have ended up bankrupt since 1997. 
were often made based on factors that were seldom related to the profitability of the public enterprises.

There have been two waves of reform efforts aimed at privatizing the public-enterprise sector. In late 1997, the Kim Young Sam administration introduced the Act for Privatization and Improvement of the Efficiency of Large Public Enterprises, generally referred to as the "Special Act on Privatization," to promote privatization of four large public enterprises. ${ }^{5}$ The act aimed at reforming corporate governance structures of commercial public enterprises to be privatized, while at the same time preventing takeover by chaebols during their privatization. The second wave of reform, initiated by the current administration that came to power at the peak of the economic crisis, is still unfolding. The current administration turned over large shares of public enterprises to private hands. It is also transforming the electricity industry from a vertically integrated public-enterprise monopoly into a competitive industry operated by private interests. However, full privatization of a large public enterprise has yet to occur.

In short, privatization is still proceeding and is far from complete. Thus, it is too early to quantitatively evaluate the outcome of the policies toward state-owned enterprises (SOEs) being privatized with any precision. ${ }^{6}$ Instead, our goal in this paper is to give an accurate description of the key aspects of the public-enterprise sector in Korea, as well as the privatization process, and to identify the remaining issues. In addition, this paper deals with the chaebol problem that worked as a barrier to privatization.

The paper proceeds as follows. Section 4.2 provides an overview of the public-enterprise sector, encompassing the institutional frameworks governing public enterprises and their characteristics and positions in relevant markets. Section 4.3 provides key financial information on public enterprises, including revenues, profits, and debt-equity ratios. This section also compares the performance of large SOEs with that of chaebol firms. One notable finding is that large SOEs are generally more efficient than chaebol firms. Section 4.4 describes the main elements of the 1997 Special Act on Privatization and analyzes the factors that led to the introduction of the act as well as its effect. Section 4.5 summarizes the privatization policies of the new administration and their results. This section deals with both institutional changes and divestiture of the government's shares and also provides analysis of some of the crucial events. Sections 4.2 through 4.5 are devoted

5. Nam and Kang (1998) offer an extensive analysis of the Special Act and of other key issues regarding the public-enterprise sector in Korea.

6. For instance, comparison of costs before and after privatization is not possible for most large commercial SOEs because they have been only partially privatized and are generally still controlled by the government. There are several small SOEs that have been completely privatized and are now controlled by private investors, but a meaningful quantitative comparison of efficiency before and after privatization is also difficult since they have been privatized only recently. 
to twenty-six nonfinancial corporations in which the government is the dominant shareholder or in a controlling position. Section 4.6 explains other forms of commercial organizations owned and controlled by the government, and the final section draws conclusions.

\subsection{An Overview of the Public-Enterprise Sector Prior to 1998}

\subsubsection{Institutional Environment}

At the end of September 1997 there were twenty-six nonfinancial corporations in which the government was the sole owner or had controlling interests. ${ }^{7}$ Many of them had several subsidiaries in which they held controlling interests. ${ }^{8}$ Most of the twenty-six corporations had strong commercial elements in the nature of their business. Some of them, such as Korea Telecom (KT) and Korea Tobacco and Ginseng (KT\&G), started as government agencies and were later transformed into corporations. Some others, such as Pohang Steel Co. (POSCO), were established as corporations from the beginning. Korea Heavy was established as a result of the merger among three ailing private firms, which were acquired by a consortium headed by Korea Electric Power Corporation (KEPCO). ${ }^{9}$

The twenty-six public enterprises were perceived by the government primarily as policy instruments rather than profit-seeking business organizations. Consequently, the shareholders' rights of each of them were given to a line ministry, which put priority on policy considerations in exercising the rights. ${ }^{10}$ Some of the public enterprises had their own corporation acts, such as the KEPCO Act and KT\&G Act, which made it clear that they were established to serve public policy objectives and explicitly gave the line ministry control of the respective public enterprise. All of the govern-

7. 1997 is a good year for comparison with the current year because it is the last year of the old regime, which had been quite stable since the late 1980s. The public-enterprise sector began to change in a fundamental way in November 1997, after the newly introduced Special Act on Privatization took effect.

8. Some of the twenty-six corporations are subsidiaries of one of the twenty-six public enterprises, at least in terms of ownership. For instance, Korea Electric Power Corporation (KEPCO), the vertically integrated monopoly in the electricity industry, was the secondlargest shareholder of Korea Heavy, which was the monopolist in the generator industry. KEPCO was also the second-largest shareholder, after the government, of Korea Gas Corporation (KOGAS), the monopolist in the importing stage as well as in the wholesale stage of the gas industry. However, it should also be noted that KEPCO did not exercise or attempt to exercise control of these two public enterprises; the government maintained exclusive control of them.

9. Korea Heavy is not the only firm to become a public enterprise as a result of rationalization measures for bankrupt private firms. For instance, Hanyang, which was once a leading construction company, went bankrupt and was acquired by the Korea Housing Corporation as a part of the rationalization measures applied to Hanyang and its stakeholders.

10. For instance, the Ministry of Commerce, Industry, and Energy (MOCIE) used its control over KEPCO to pursue its own policy objectives, while the Ministry of Information and Communications (MIC) exercised its control over Korea Telecom. 
ment-owned corporations had such acts, ${ }^{11}$ while among the governmentinvested corporations, only Korea Broadcasting System, Korea Chemical, and KTB were subject to such acts. ${ }^{12}$ Whereas the rest of the governmentinvested corporations were not subject to such individual corporation acts, they were still controlled by their respective line ministries, although to a lesser degree. ${ }^{13}$

Some of the twenty-six corporations were also subject to the industry acts that govern the firms in an industry to which a public enterprise belonged. Public enterprises that were monopolistic or dominant in their industries were significantly affected by the industry acts, as they constituted all or much of the relevant industries. In addition, some of the twenty-six public enterprises that were classified as government-owned corporations by the Framework Act were subject to additional constraints set by that act.

Corporations in which the government had a controlling interest were, and still are, classified into two groups: government-owned corporations (GOCs, or tooja-gigwan) and government-invested corporations (GICs, or choolja-gigwan), depending on whether they were subject to the Framework Act for GOCs. The general rule that differentiated GOCs from GICs was government ownership. In October 1997, all of the twenty-six corporations (except Korea Broadcasting System) in which the government's share was 50 percent or higher were subject to the Framework Act. The reason that Korea Broadcasting System, which was and still is 100 percent owned by the government, was exempt from the Framework Act is not clear.

Government-owned corporations were generally perceived as more closely related with public policy objectives. In other words, GICs were viewed as having stronger commercial elements by the government and were thus allowed to enjoy greater freedom in their operations. In particular, GOCs were subject to the restrictions set by the Framework Act, which was similar in many respects to the set of restrictions applied to government agencies. The Framework Act basically perceives a GOC as a subsidiary of the line ministry and tries to constrain the management of the GOC to achieve the policy objectives set by the line ministry with as little cost as possible.

Table 4.1 summarizes the main businesses and market positions of twenty-six GOCs and GICs. As one can see from the table, almost all GOCs are monopolies in their respective markets. Most GOCs sell their goods or services mostly to the government. On the other hand, all of the GICs sell their goods or services to nongovernment consumers.

11. For instance, KT was subject to the KT Act, and KEPCO was subject to the KEPCO Act.

12. Explained further in the next paragraph.

13. For instance, POSCO was controlled by MOCIE, which used its control over POSCO to keep domestic steel prices from exceeding a certain level. 


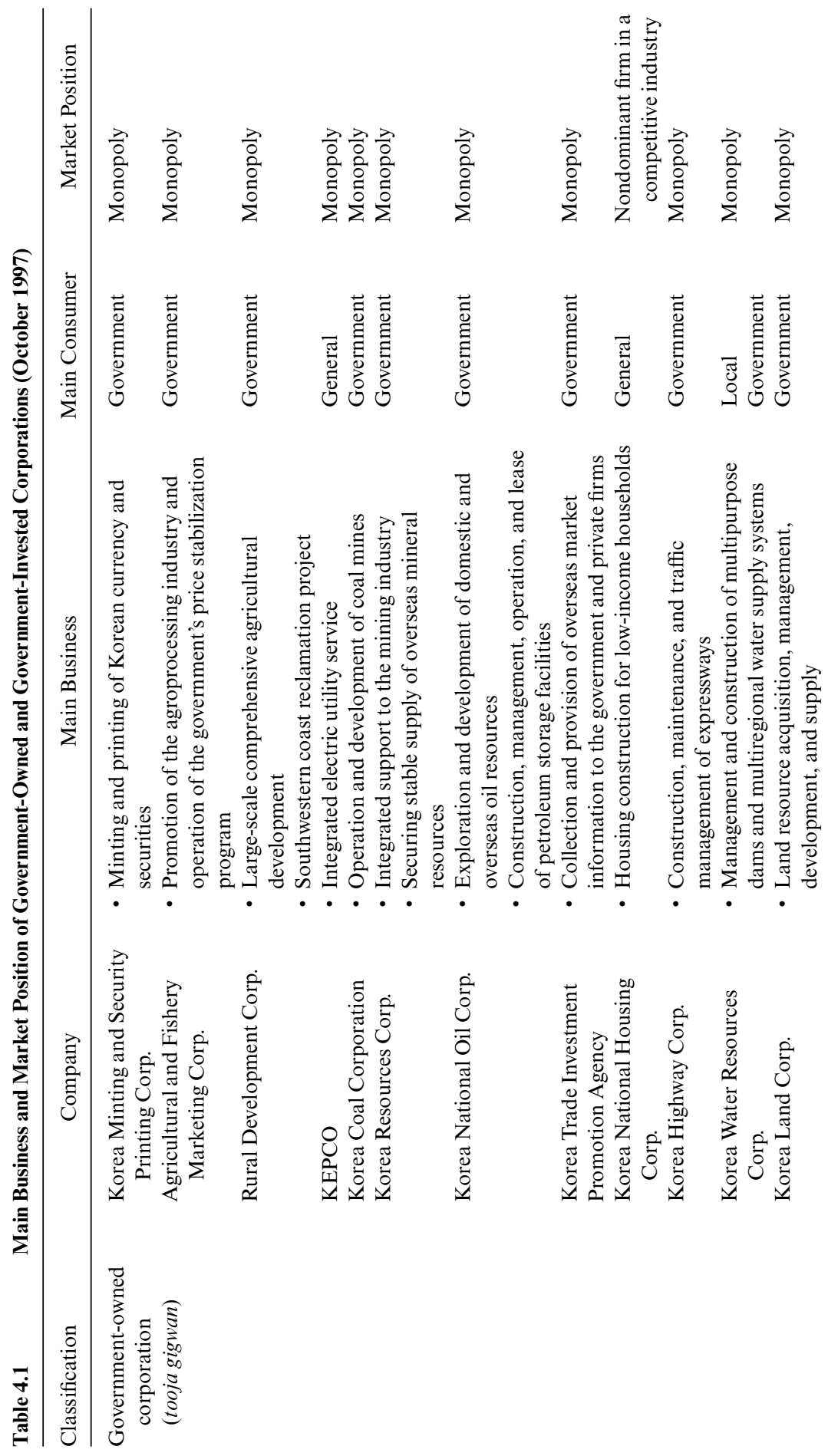




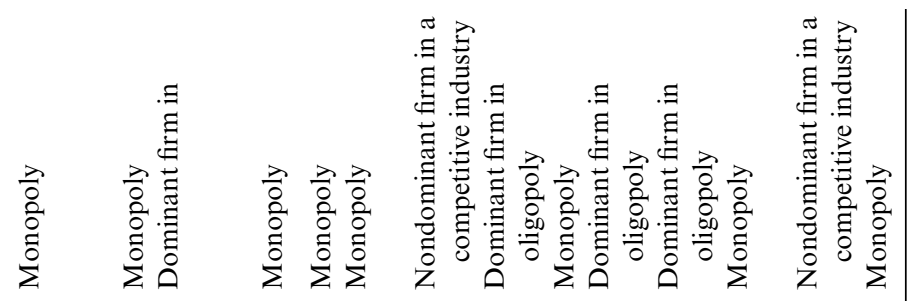

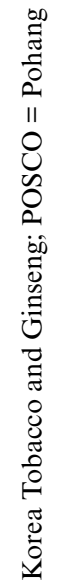
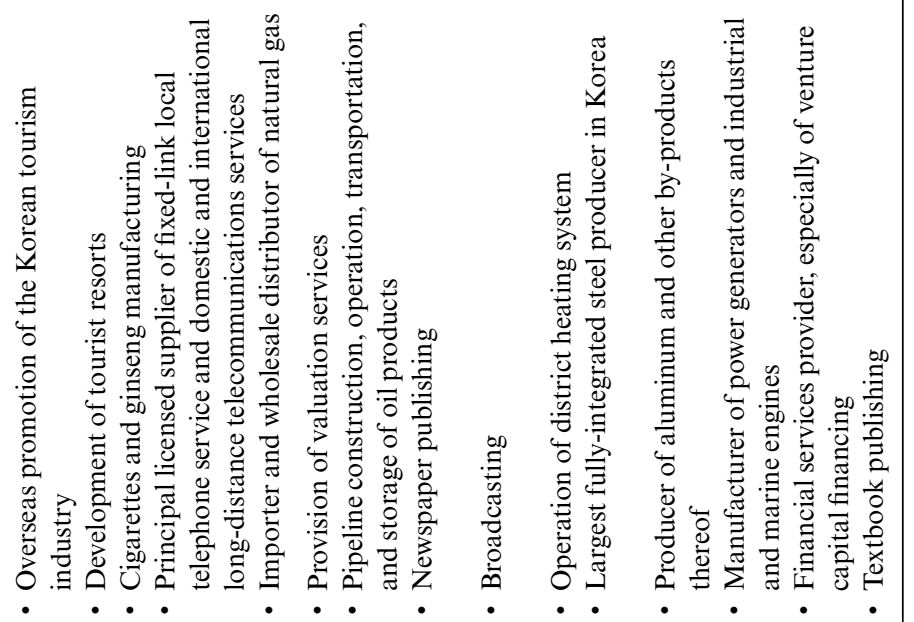

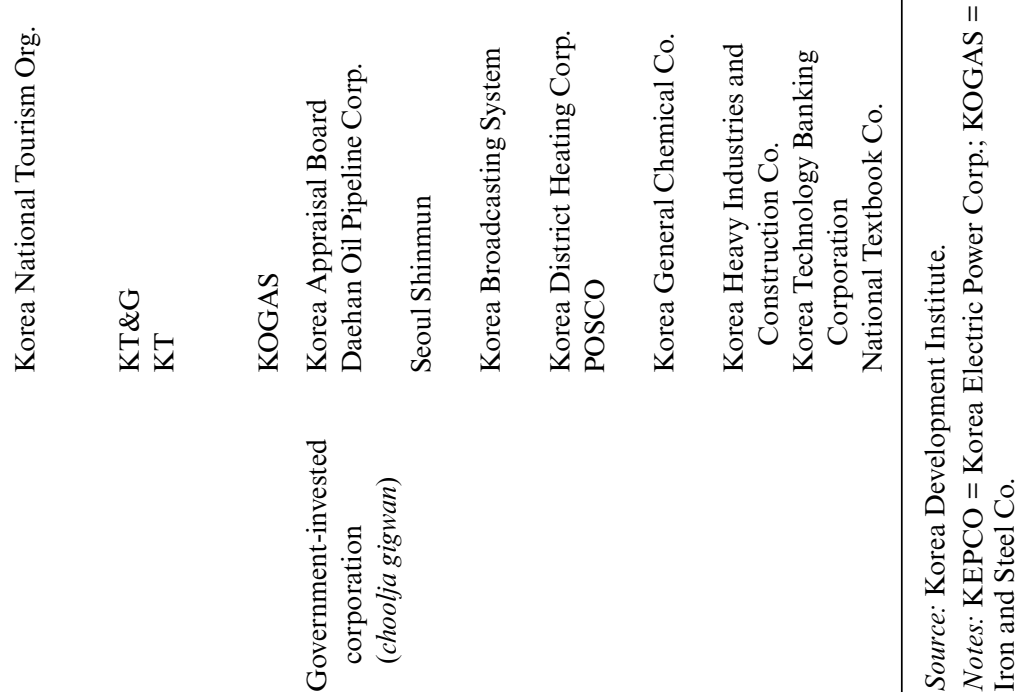

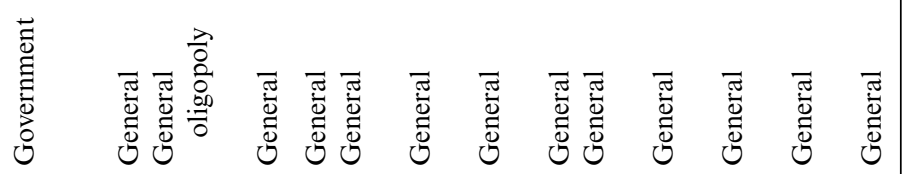

\begin{tabular}{l}
11 \\
0 \\
\multirow{2}{*}{} \\
$\forall$
\end{tabular}

हี่

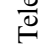

Ð̋

章

อั

త్ర

ปั0 


\subsubsection{Governance of Public Enterprises Prior to November 1997}

Who are the stakeholders of SOEs? Who controls them, and to what ends? Stakeholders of SOEs include employees and managers, just as in private firms. But the most important stakeholders are the bureaucrats and politicians. Bureaucrats and politicians control SOEs, as they control the government, who owns SOEs. The nature of ownership and control of an SOE differs fundamentally from that of a private firm in two respects. First, as the owner or a dominant shareholder, the government pursues not only financial return but policy objective as well. Second, bureaucrats and politicians who control SOEs on behalf of the general public have no personal financial stake in SOEs, unlike shareholders of private firms.

Pursuing two potentially conflicting goals often led to suboptimal outcomes in the overall performance. Designing proper incentive mechanisms that motivate managers and employees of SOEs to try to hit the right balance between policy goals and financial goals became increasingly difficult as the size of the operation of SOEs became larger, while the overall economy became larger and more sophisticated. Properly allocating authority over SOEs among various government branches became increasingly difficult. As a result, the governance structure of SOEs has evolved over time, responding to the changes in economic conditions.

The governance of a public enterprise before the introduction of the 1997 Special Act on Privatization depended on whether it was subject to the Framework Act. The Framework Act required that a GOC board consist of a member from the line ministry and another from the then-Economic Planning Board, ${ }^{14}$ and the rest from outside the government. The board members who were not from the government were mainly lawyers and professors appointed by the government. The board reviewed and made decisions on the issues of importance, such as key investment decisions and appointment of executives. In reviewing and making decisions on the agenda, the board was required by the act to put priority on public policy considerations.

Although there were nine board members, the one from the line ministry played a decisive role. The board member from the economic planning board played a secondary role of checking for wasteful activities. The remaining members from outside the government generally were not expected to play a significant role and usually approved an agenda that had already been negotiated by the two members from the government. The board member from the line ministry intervened heavily with the management of a GOC. The board members were paid only token amounts of

14. The Economic Planning Board was charged with the task of planning and budgeting as well as that of coordinating economic policies of various ministries. The board later merged with the Ministry of Finance. 
money for their services and did not have any monetary incentives in the financial performance of the public enterprise for which they worked.

The chief executive officers of the GOCs were selected by the government without active participation of the board. Political appointment was not rare. The rest of the top executives were usually selected from the bureaucracy of the GOCs themselves. Appointment of ex-government officials to a GOC position other than chief executive officer was barred by law. Executive pay was generally lower than that in private firms. Incentive-based management contracts were not used. Top executives, in particular the chief executive officers, usually considered themselves as bureaucrats belonging to the government rather than executives of a business organization.

The GOCs had to submit annual budget plans to the government, which regularly evaluated their performance. In addition to being subject to a strict quota on the number of employees and the number of managerial positions, they were also regularly audited by the Office of the Inspector General and the National Assembly.

The corporate governance of GICs was similar to that of GOCs, although GICs were not subject to any law that specified a particular governance model. However, they were granted more autonomy compared with GOCs. The line ministry generally was given shareholder's rights and could successfully control a GIC in a way that suited its policy objectives.

One peculiar aspect of the public enterprises in Korea is that, although they were officially treated as policy instruments, many of them had private shareholders. The best example is KEPCO, which was and still is a GOC subject to the Framework Act as well as the KEPCO Act and the Electricity Industry Act. The three acts all stipulate that KEPCO should be run primarily as an instrument that the government could use in pursuing its policy objectives related to the electricity industry. In reality, KEPCO has indeed been run basically as a policy instrument, as the acts intended; but the government sold its shares of KEPCO in several tranches to private investors, including a large number of foreign investors. Korea Telecom is another example. The first tranche of KT shares was sold to domestic investors in 1994 while KT was a GOC. Sales of GOC shares to private investors raise the question about the nature of those GOCs. ${ }^{15}$

\subsection{Sizes and Financial Performance of Public Enterprises}

\subsubsection{Size of Operation and Financial Performance of Public Enterprises}

This section attempts to describe SOEs in key aspects, such as size, profitability, and financial stability. After summarizing key statistics for large

15. It is not clear to me why the investors purchased the shares of KT and KEPCO at the time. 
SOEs, we compare the performance of commercial SOEs with that of chaebol firms.

Table 4.2 contains key statistics for the twenty-six GOCs and GICs. For most GOCs that sell their services almost exclusively to the government, profits do not seem to be an important measure of managerial efficiency. Revenues of these public enterprises may be viewed as budgets allocated to them by the government for certain activities they perform on behalf of the government. Korea Coal Corporation kept accumulating large amounts of losses, as it was supposed to subsidize failing coal mines. Such large losses are not a result of internal inefficiency of Korea Coal. Similarly, large revenues or profits of GOCs such as Korea Trade Investment Promotion Agency, Korea National Housing, Korea Highway Corporation, and Korea Land Corporation are not likely to be a result of their internal efficiency.

Some GICs that look promising in table 4.2 may not be profit-oriented, efficient business organizations. For instance, Korea Broadcasting System is not considered to be a profit-oriented business organization, although it has enjoyed the status of a GIC for quite a while. Its stable profitability comes mainly from a guaranteed source of revenue, fees collected from all television owners. ${ }^{16}$ The other two network broadcasting companies (Munhwa Broadcasting Corporation and Korea Broadcasting System) are not entitled to the TV viewing fees. Korea Broadcasting System is also competing with the other two networks in the market for advertisement time. ${ }^{17}$

The public enterprises for which meaningful discussions on commercial performance can be made are the "Big Six" and a handful of GICs. The Big Six are KEPCO, KT, KT\&G, POSCO, Korea Gas Corporation (KOGAS), and Korea Heavy. Among the Big Six commercial public enterprises, KOGAS and Korea Heavy did not earn as much profit as the other four. KOGAS is still in the stage of building a national transmission network and has been investing more cash than it has generated. Korea Heavy depends on KEPCO, one of its major shareholders, for a large part of its revenue. As a consequence, its accounting profits are believed to depend heavily on the terms that govern its contracts with KEPCO.

It will be interesting to compare operating efficiency of various SOEs as well as that of SOEs and large private firms, almost all of which were chaebol affiliated until very recently. However, direct comparison of, say, costs of operation turned out to be quite complicated and seems beyond the scope of this paper. ${ }^{18}$ Comparison of profitability based upon accounting data

16. Fees are for watching TV programs produced and aired by Korea Broadcasting System.

17. Korea Broadcasting System offers two main channels, one of which provides advertisements.

18. In almost all cases, SOEs operate in completely different industries. Further, most commercial SOEs are monopolistic and do not have private competitors providing the same services competing with them. In addition, cost data of many chaebol firms turned out to be false, and are being corrected. An empirical analysis of the comparative efficiency of SOEs and chaebol firms that takes these factors into account is beyond the scope of this paper. 


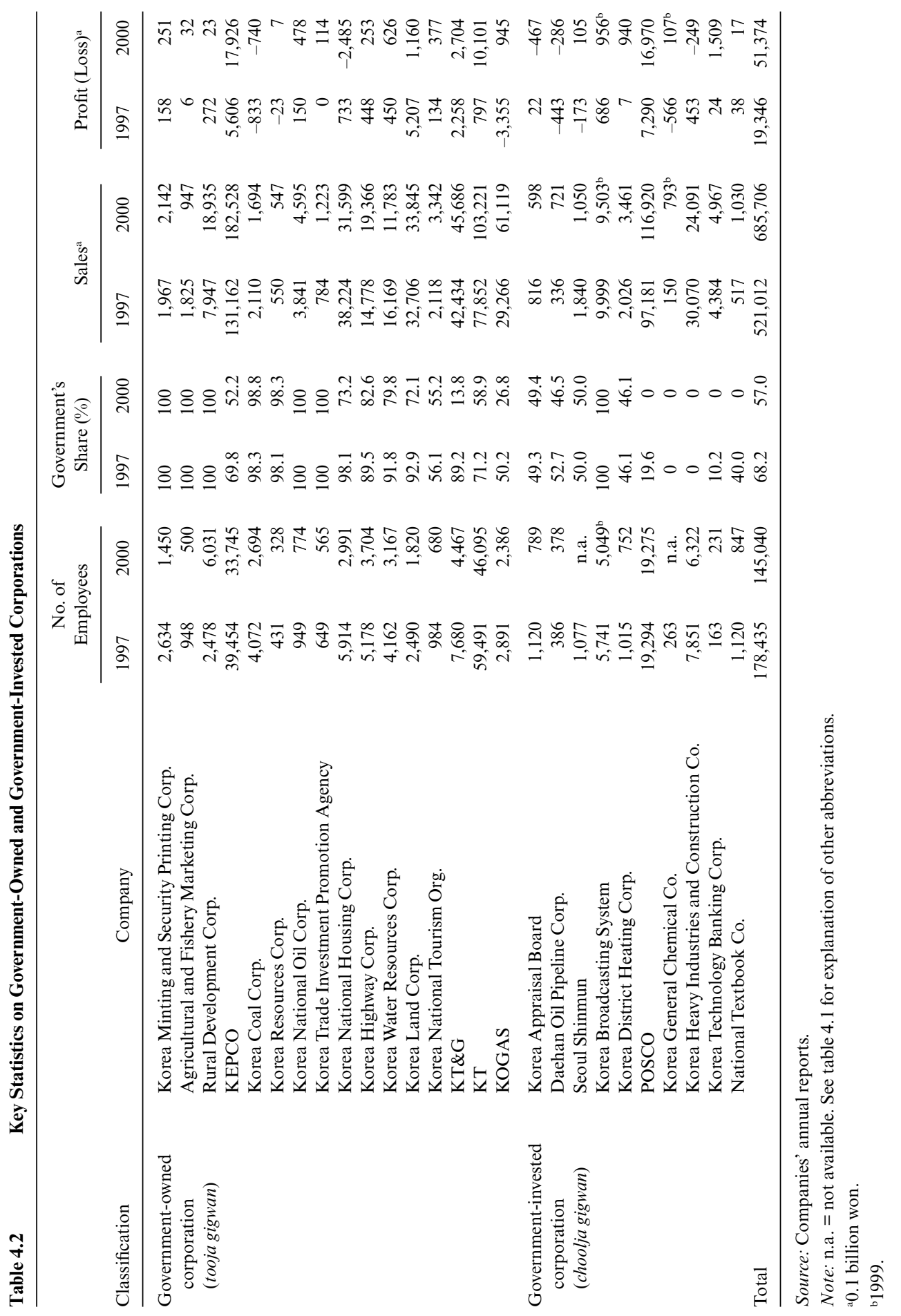


Profit Leaders among Listed Companies (unit: 0.1 billion won)

\begin{tabular}{|c|c|c|}
\hline Rank & Company & Profit \\
\hline 1 & Samsung Electronics & 60,145 \\
\hline 2 & КЕРСО & 17,925 \\
\hline 3 & POSCO & 16,369 \\
\hline 4 & KT & 10,101 \\
\hline 5 & SK Telecom & 9,506 \\
\hline 6 & Hyundai Motors & 6,678 \\
\hline 7 & Samsung SDI Co. & 5,439 \\
\hline 8 & LG Electronics & 5,021 \\
\hline 9 & Kia Motors & 3,307 \\
\hline 10 & LG Chemical & 3,248 \\
\hline 11 & LG Chemical Investment & 3,248 \\
\hline 12 & KT\&G & 2,704 \\
\hline 13 & Shinhan & 2,631 \\
\hline 14 & Hanil Synthetic Fiber & 2,592 \\
\hline 15 & SK Telecom & 1,447 \\
\hline 16 & LG Construction & 1,235 \\
\hline 17 & Hyundai Mobis & 1,131 \\
\hline 18 & Anam Electronics & 1,081 \\
\hline 19 & Hanwha & 1,056 \\
\hline 20 & Dongbu Construction & 1,039 \\
\hline 21 & KOGAS & 944 \\
\hline 22 & PacInd & 847 \\
\hline 23 & LG Industrial System & 823 \\
\hline 24 & Hyundai Dept. Store & 801 \\
\hline 25 & Samsung Corp. & 750 \\
\hline 26 & Pungsan & 729 \\
\hline 27 & HITE Brewery & 701 \\
\hline 28 & Shinsegae & 697 \\
\hline 29 & Kumkang Korea Chemical & 677 \\
\hline 30 & Inchon Iron and Steel & 635 \\
\hline
\end{tabular}

Source: Korea Stock Exchange (December 2000).

Note: See table 4.1 for explanation of abbreviations.

also has its limitation, as most SOEs are monopolistic while most of chaebol firms face competition in their industries. In this paper, we will not attempt to directly compare operating efficiency of SOEs and chaebol firms and will only compare various financial ratios, which can serve as indirect signals. ${ }^{19}$

The "Big Four" (the Big Six minus KOGAS and Korea Heavy) are the most important commercial firms owned by the Korean government. They consistently turn out large profits and generally sustain stable growth. Table 4.3 shows the profits earned by the top thirty performers among the

19. We believe that a meaningful analysis can be accomplished by comparing Korean firms with their counterparts in other countries. Such a comparative study seems to be appropriate for a separate research. 
listed companies in 2000. KEPCO, POSCO, and KT ranked second, third, and fourth after Samsung Electronics. Table 4.3 may be biased in favor of nonpublic enterprises because it is based upon accounting reports of the listed companies. It has been discovered in the aftermath of the economic crisis that accounting reports of many private companies contained serious flaws. Accounting reports from public enterprises have never been subject to allegations of serious wrongdoing. Thus, the Big Four could be in an even more dominant position if standard accounting practices had been used.

As of April 2001, KT ranked fourth after Samsung Electronics, SK Telecom, and Korea Exchange Bank in terms of the size of the market capitalization among listed firms. ${ }^{20} \mathrm{KEPCO}$ ranked fifth and was immediately followed by POSCO. KT\&G and KOGAS ranked fourteenth and twenty-seventh, respectively. In terms of the percentage of market capitalization to the total market capitalization of all listed firms, KT, KEPCO, POSCO, KT\&G, and KOGAS recorded 8.6, 6.4, 4.1, 1.3, and 0.5 percent, respectively. ${ }^{21}$

Combined, the Big Six, and certainly the Big Four, fared better than the market average in terms of their financial performance. Table 4.4 compares the returns on investment, interest coverage ratios, and debt-equity ratios of the Big Six public enterprises with the market average of the listed companies. Earnings per share for the Big Six were consistently higher than the market average of the listed companies, both before and after the economic crisis. Weak performance of KEPCO and KOGAS in 1997 is due to the large appreciation of the dollar against the Korean won that occurred that year during the economic crisis. KEPCO had a large portion of loans expressed in foreign currencies, while KOGAS imports all of the natural gas it sells from abroad.

With respect to interest coverage ratios and debt-equity ratios, which began receiving increasing attention as key financial indices since the onset of the crisis, the public enterprises fared significantly better than their counterparts in the private sector. Four public enterprises show debt-equity ratios that are far below the market average. ${ }^{22}$ The high debt-equity ratio of KOGAS is due to the high rate of investment using borrowed money that resulted from expansion of the national gas transmission network. Interest coverage ratios of the public enterprises have been much higher than the market average. Weak performance of KEPCO in 1997 is due to the rapid

20. SK Telecom used to be a subsidiary of KT, but became a subsidiary of SK Group after 1994.

21. Samsung Electronics, SK Group, and Korea Exchange Bank recorded 16.2, 8.8, and 8.7 percent, respectively.

22. The interest coverage ratio of a firm is defined to be the amounts that the firm has to pay as interest on its debts divided by the operating profit (before paying interests) in a given year. A firm earns a gross profit that is just enough to pay interests when its interest coverage ratio is equal to 1 . 
Table 4.4

Financial Ratios of the Big Six Public Enterprises

\begin{tabular}{|c|c|c|c|c|c|}
\hline Classification/Company & 1996 & 1997 & 1998 & 1999 & 2000 \\
\hline \multicolumn{6}{|l|}{ Net income to stockholder's equity ratio } \\
\hline KT\&G & 8.63 & 9.24 & 11.23 & 11.01 & 9.76 \\
\hline POSCO & 9.49 & -2.27 & 9.87 & 17.15 & 17.36 \\
\hline KOGAS & 16.36 & -48.76 & 13.03 & 10.14 & 4.04 \\
\hline KT & 0.21 & 0.60 & 2.93 & 2.81 & 8.84 \\
\hline KEPCO & 3.15 & -3.62 & 6.29 & 4.84 & 5.63 \\
\hline Doosan Heavy Industries and Construction Co. & 15.21 & -7.90 & 4.41 & 1.56 & -1.49 \\
\hline Weighted average of listed companies & $\begin{array}{c}2.96 \\
(627)\end{array}$ & $\begin{array}{c}-16.04 \\
(630)\end{array}$ & $\begin{array}{l}-8.69 \\
(625)\end{array}$ & $\begin{array}{l}-8.17 \\
(570)\end{array}$ & $\begin{array}{c}0.25 \\
(628)\end{array}$ \\
\hline Weighted average, excluding Big Six firms & 1.9 & -22.74 & -15.25 & -15.08 & -3.41 \\
\hline \multicolumn{6}{|l|}{ Interest coverage ratio } \\
\hline KT\&G & 469.21 & 467.03 & 443.77 & 1729.72 & 912.41 \\
\hline POSCO & 2.75 & 0.97 & 3.13 & 8.07 & 7.60 \\
\hline KOGAS & 3.09 & -1.55 & 1.78 & 2.49 & 1.50 \\
\hline KT & 3.27 & 2.11 & 3.02 & 4.01 & 4.80 \\
\hline KEPCO & 2.02 & -0.16 & 2.91 & 3.23 & 2.95 \\
\hline Doosan Heavy Industries and Construction Co. & 4.91 & 0.67 & 2.18 & 1.27 & 0.50 \\
\hline Weighted average of listed companies & $\begin{array}{c}1.31 \\
(627)\end{array}$ & $\begin{array}{c}0.36 \\
(630)\end{array}$ & $\begin{array}{c}0.75 \\
(625)\end{array}$ & $\begin{array}{c}0.70 \\
(570)\end{array}$ & $\begin{array}{c}1.30 \\
(628)\end{array}$ \\
\hline Weighted average, excluding Big Six firms & 1.18 & 0.34 & 0.62 & 0.48 & 1.04 \\
\hline \multicolumn{6}{|l|}{ Debt-equity ratio } \\
\hline $\mathrm{KT} \& \mathrm{G}$ & 24.79 & 31.53 & 24.85 & 29.01 & 38.08 \\
\hline POSCO & 118.50 & 160.48 & 118.85 & 89.59 & 88.41 \\
\hline KOGAS & 230.23 & 555.79 & 273.70 & 184.22 & 259.02 \\
\hline KT & 189.34 & 223.98 & 192.33 & 75.69 & 103.32 \\
\hline KEPCO & 112.89 & 185.23 & 175.23 & 111.50 & 102.70 \\
\hline Doosan Heavy Industries and Construction Co. & 186.91 & 243.66 & 127.35 & 139.11 & 113.50 \\
\hline Weighted average of listed companies & $\begin{array}{c}265.31 \\
(627)\end{array}$ & $\begin{array}{c}415.35 \\
(630)\end{array}$ & $\begin{array}{c}316.43 \\
(625)\end{array}$ & $\begin{array}{l}199.73 \\
(570)\end{array}$ & $\begin{array}{c}205.52 \\
(628)\end{array}$ \\
\hline Weighted average, excluding Big Six firms & 326.41 & 532.08 & 382.75 & 246.20 & 253.14 \\
\hline
\end{tabular}

Source: Korea Development Institute.

Notes: Numbers in parentheses are the number of firms in the sample. See table 4.1 for explanation of abbreviations.

depreciation of the Korean won. Thus, the public enterprises do not seem to be facing the possibility of serious financial trouble, which has threatened a large part of the corporate sector since the mid-1990s.

\subsection{Special Act on Privatization: A First Step toward Privatization}

Most of the large SOEs that exist today were formed in 1980s or earlier. The system by which SOEs operate was also formed in the mid-1980s and remained unchanged until the end of the Roh Tae Woo administration. There did not exist significant demand for privatization either; reason for this low demand can be summarized as follows. First, there was a general 
consensus that SOEs were the only feasible, and probably the most efficient, way to build much-needed infrastructure, such as national telecommunications, electricity, gas networks, and highway networks. Second, chaebols that had been given various subsidies from the government concentrated on expanding their territory in export industries as well as some domestic industries that lay outside of the domains of SOEs. Third, there was little understanding of how different economic systems worked at the time. There were few bureaucrats or politicians who could distinguish between commercial objectives and the public goals of an SOE. Fourth, there was no political pressure to privatize SOEs.

In 1994, the Kim Young Sam administration, during its second year in power, commissioned a comprehensive study of several public enterprises, including $\mathrm{KEPCO}, \mathrm{KT}$, POSCO, and $\mathrm{KT} \& \mathrm{G}$. It is not clear what motivated the study. However, one can point out the following changes in the economic environment, which appear to have affected the change in the government's attitude toward SOEs. First, most of the basic infrastructure investment was completed in most of the industries mentioned above. Second, chaebols had been given a more favorable and generous treatment from the Roh administration, and gained freer access to the financial market. Third, privatization somehow became one of the key economic policies of the Kim Young Sam administration, which kept pushing for a tangible outcome. It is worth noting that financial losses of SOEs were not a factor behind the push for privatization, as all SOEs subject to the study, except for Korea Heavy, were very profitable.

The study reviewed, among other things, the possibility of privatizing each of the public enterprises. The results of the studies for KT\&G, $\mathrm{POSCO}$, and KT generally concluded that a significant degree of loss of efficiency existed due to their governance structures and that privatization would produce more efficient outcomes. By the end of 1996, a consensus was building up within the government that privatization was needed for some of the commercial public enterprises.

The possibility of privatizing large public enterprises immediately raised the question of whether chaebols should be allowed to purchase controlling interests. At that time, the problem with selling public enterprises to chaebols seemed only political in nature, as there existed a widespread strong sentiment against handing over the large, commercial public enterprises to chaebols. ${ }^{23}$ It appears that most policymakers at the time believed that it

23. At that time, there were few, if any, who expected that the economic crisis was on its way. The economic crisis revealed that chaebol were able to set up and maintain control of large firms only by heavy government intervention in the financial market. It also revealed that chaebol were neither particularly efficient nor able to raise capital needed to purchase controlling interests of large firms on their own through proper market mechanisms. In fact, many chaebol went bankrupt. After the economic crisis, the chaebol issue began to be analyzed from a very different angle. 
was politically unfeasible to allow chaebols to acquire controlling interests. ${ }^{24}$ Thus, it was decided that chaebols would not be allowed to take control of the public enterprises to be privatized.

The government forecast quite correctly that a large-scale sale of the shares of large public enterprises to domestic investors would be difficult to achieve. Large-scale sale to foreign investors was also excluded from consideration for a variety of reasons. As a consequence, it appeared inevitable that the government had to maintain dominant ownership of large public enterprises for quite a while. Thus, there arose the question about the governance of the commercial public enterprises that would eventually be privatized during the period in which the government remained a major shareholder. The need for the separation of public policy objectives from the commercial operation of the public enterprises was also acknowledged for the first time. The 1997 Special Act on Privatization was introduced to address these issues.

The act targeted four public enterprises, KT\&G, KT, KOGAS, and Korea Heavy, and had two main elements. First, it put restrictions on the ownership of all four public enterprises in order to prevent chaebols from acquiring controlling interests. Specifically, the act required that the combined share of any investor, including the shares held by the parties who are in intimate relations with the investor, should not exceed 15 percent of each of the four public enterprises.

Second, the act prescribed an Anglo-Saxon-style corporate governance structure for the four public enterprises. The act stipulated that the board must consist of only civilians, thus removing the presence of the line ministry as well as the Ministry of Finance and Economy ${ }^{25}$ from the board. It also gave the board power similar to that of a typical board in large firms in the United Kingdom or United States. The act even contained detailed procedures for selecting chief executive officers, which were aimed at guaranteeing transparency in the selection process.

In addition, the Framework Act was amended to exempt KT\&G, KT, and KOGAS from the application of the act, thus making them GICs, even though the government's share in each of these companies exceeded the 50 percent benchmark. Further, the KT Act and KT\&G Act were abolished. These two measures removed many of the constraints rooted in the policyrelated concerns of the line ministry that bound the commercial operation of $\mathrm{KT}$ and $\mathrm{KT} \& \mathrm{G}$, thus basically making them private common-stock companies subject to company laws. Legally, they differed from a private company only to the extent that they were subject to the Special Act and

24 . Their assessment seems to have correctly reflected the political reality.

25. There was a change in the government itself in which the Economic Planning Board merged with the Ministry of Finance to form the Ministry of Finance and Economy. The authority of the old Economic Planning Board concerning public enterprises was passed on to the newly formed ministry. 
the industry acts. The KOGAS Act was left intact because its line ministry (the Ministry of Commerce, Industry, and Energy, or MOCIE) successfully argued that the KOGAS Act was needed to enable MOCIE to complete the national gas-transmission network within the target period. Thus, KOGAS was freed from the constraints given by the Framework Act, but was left to the control of the line ministry and its policy concerns.

The spirit of the act was clear. The act envisaged that the four public enterprises would develop into large, commercial, private firms to be run by professional managers who strive to maximize the shareholders' monetary interests. It also recognized the need for the separation of policy concerns from commercial operation and attempted to restrain the line ministries in their dealings with the public enterprises. The act was quite successful in achieving the goals that were the motivation behind the act. By prohibiting chaebols from acquiring controlling interests of the four public enterprises, it ended a long dispute that worked as a barrier to privatization, and thus enabled privatization to proceed. ${ }^{26}$ The act also allowed the three former GOCs, in particular KT and KT\&G, to be run basically as profit-seeking firms. Finally, it installed a corporate governance mechanism that was in line with large profit-oriented firms, at least on the surface.

However, the Special Act and the other privatization measures introduced in 1997 were far from a complete privatization package and even contained some crucial flaws. The act failed to completely sever the ties with policy consideration and allowed the line ministry to maintain shareholders' rights. It also contained a clause that explicitly stated that the management of the public enterprises must consider public policy objectives when making decisions. Such clauses are not consistent with the rest of the act or its spirit. The clause that leaves the shareholders' rights in the hands of the line ministry left the door open for the line ministry to intervene in the management of public enterprises to promote its policy concerns. The act also left the four public enterprises subject to audits by the Office of the Inspector General and the National Assembly. ${ }^{27}$

Another criticism directed at the privatization measures taken in 1997 concerned the target firms. It was difficult to understand why POSCO was not included in the list of target firms, while KT\&G and Korea Heavy were included, as there were few public policy objectives with which one could identify POSCO. ${ }^{28}$ Exclusion of KEPCO also was hard to understand considering that KT and KOGAS were included and that KEPCO

26. I believe that it also provided part of the solution to the chaebol problems, although few were aware of the issue at the time, and the act did not intend to solve the fundamental problems associated with the chaebol. It was revealed later on that the expansion of the chaebol groups, based upon financial transactions that lack transparency and accountability, was one of the main culprits for the recent economic crisis.

27. Private firms are not subject to such audits.

28. For instance, one of the functions $K T \& G$ performed on behalf of the government was subsidizing the tobacco-growing farmers in Korea. 
had the highest proportion of private ownership among the three network giants.

It is also worth noting that regulatory reforms accompanying the partial privatization of KT by the Special Act have not occurred. The Communications Commission had existed not as an independent regulatory body, but as a part of KT's line ministry, the Ministry of Information and Communications (MIC). The commission was not even given the authority over regulating rates and access charges, which was handled directly by the MIC. Little changed on the regulation front after the Special Act took effect. The same was true for the gas and electricity industries.

Overall, the special act was incomplete as a privatization measure. It even failed to secure logical consistency in some respects, as mentioned above. As a result, it was only half successful in inducing the effect of privatization. However, it was the greatest step in the direction of privatization ever taken by Korea until that time. It also opened a new chapter in corporate governance of large, commercial enterprises in Korea, as it was the first-ever attempt in Korea at installing an advanced form of corporate governance in large firms. At the time, corporate governance was not even an issue for private firms as most people took for granted the absolute control by dominant shareholders of chaebol firms.

\subsection{Privatization Drive after the Economic Crisis}

\subsubsection{Privatization Plan of 1998}

In March 1998, a new government succeeded the Kim Young Sam administration at the peak of the economic crisis. The new government had to implement measures aimed at reducing employment and the size of operations of many private firms and financial institutions that were bankrupt to rehabilitate them. There was political pressure from labor and chaebols alike that the bureaucracy should share the pain as well. At the time, it was generally acknowledged that SOEs had sizable room for improving efficiency, although they were in good financial health, unlike private firms. Thus, the new government introduced measures aimed at restructuring public enterprises in its early days in power. The focus was given to reduction in unneeded workers, removal of redundant operations, and sales of assets and businesses of public enterprises that were not essential for operation.

Privatization received secondary attention as it was acknowledged to be more difficult than restructuring, involving plans on market structures and regulatory frameworks. However, some within the new government expected that they would eventually have to sell SOEs to raise money to cover the costs of corporate and financial restructuring. There was also a need to raise foreign capital to increase the foreign currency reserve, the depletion 
of which was believed by many to have caused the economic crisis. ${ }^{29} \mathrm{Con}-$ trary to what many believe, neither the International Monetary Fund nor the World Bank played a significant role in shaping policies on public enterprises in Korea.

The Budget and Planning Commission, a new government agency created by the new administration, announced an ambitious privatization and restructuring plan that covered 108 public enterprises. ${ }^{30}$ The 1998 plan classified public enterprises into three groups and prescribed different solutions for each of them.

The first group is the set of public enterprises to be privatized. POSCO, Korea Heavy, Korea Chemical, KTB, and Korea Textbook were included in this group, along with twelve subsidiaries of various GOCs and GICs. The second group consists of the public enterprises that eventually need to be privatized, but would not be privatized in the near future. It includes KT, KT\&G, KEPCO, KOGAS, Daehan Oil Pipeline, and Korea District Heating, as well as twenty-eight subsidiaries of GOCs and GICs. The third group is the set of public enterprises that would not be privatized. Thirteen GOCs were included as well as fourteen subsidiaries of some GOCs and GICs.

The Ministry of Planning and Budget's (MPB's) prescription for the first group of public enterprises was to turn the shares of each over to private hands and let the new owners run them based upon profit incentives. It is noteworthy that, in the case of Korea Heavy, the government changed the previous administration's policy on chaebol ownership of large public enterprises. The government subsequently amended the Special Act and excluded Korea Heavy from the list of public enterprises covered by the act. The main reason for this change was the government's realization that the best and probably the only feasible way to privatize Korea Heavy was through a trade sale or sale of controlling interests to a single party.

For the second group, gradual privatization was proposed as the solution. The meaning of "gradual privatization" was unclear from the moment it was announced and has never been well understood. The GOCs and GICs belonging to the second group were all monopolistic firms in network industries, except for KT\&G. Privatization of monopolistic public enterprises in the network industries requires a wide range of changes in regulatory and industrial policies. It could also lead to fundamental changes in the organization of the line ministries. Privatization of KT\&G also inevitably entails a fundamental change in the industrial policies for the tobacco-growing industry, which could prove to be a difficult task. It seems that the MPB acknowledged the need to privatize those public en-

29. Even many chaebol firms tried to sell assets and businesses of some of their firms to meet the demands by the government to increase liquidity, reduce debts and costs, and raise foreign capital.

30. The commission changed its name to the Ministry of Planning and Budget a year later. 
terprises, but also realized that their privatization requires complex and far-reaching changes in regulatory and industrial policies that were beyond its control when it announced "gradual privatization" as the solution to the second group of public enterprises.

For the third group of public enterprises, privatization was not an option. The MPB's solutions for the third group of public enterprises were internal restructuring or liquidation. Some public enterprises were determined to lack public policy concerns that could justify their existence as public enterprises as well as any marketable commercial value. Hanyang was the best example. It was determined to be liquidated. Most other public enterprises belonging to the third group were allowed to continue to operate as before, but were subject to a heavy dose of the internal restructuring program, which entailed a large reduction in employment and in the scope of the business. ${ }^{31}$

The 1998 privatization plan (see table 4.5) was far more comprehensive in scope and depth than any other privatization effort by the previous administrations. The 1998 privatization plan has changed considerably in the implementation stage. However, it served as the skeleton of the new administration's policy for public enterprises.

\subsubsection{Other Measures and Recent Developments in Privatization}

\section{Special Act}

The new government left most of the contents of the Special Act intact. ${ }^{32}$ Thus, the ceiling on the ownership of some of the large public enterprises was left unchanged, as was the governance structure for them. The shareholders' rights of the government in the public enterprises covered by the act were still left to the line ministries. The government kept making changes to the list of public enterprises to be covered by the act. Korea Heavy was later dropped, as mentioned above, while some smaller public enterprises were added.

\section{Framework Act}

The new administration amended the Framework Act and changed the governance structure of GOCs to the one specified by the Special Act. Thus, GOCs are now governed by a board whose members are recruited from outside the government. The new governance structure could be con-

31. Intense shake-ups also fell on most of the public enterprises belonging to the other groups as well. To a certain degree, such shake-ups were taken to cut unnecessary costs that were due to inefficient management of the public enterprises. The scope and depth of restructuring of the public enterprises also appear to have been affected by the onset of the economic crisis.

32. Korea Heavy was excluded from the act, as mentioned earlier. There also were some other relatively minor changes. 
Solutions/Targeted GOCs and GICs

Complete privatization

Pohang Iron and Steel Co.

Korea Heavy Industries and Construction Co.

Korea General Chemical Co.

Korea Technology Banking Corp.

National Textbook Co.

Subtotal $=5$

Gradual privatization

KT

$\mathrm{KT} \& \mathrm{G}$

KEPCO

KOGAS

Daehan Oil Pipeline Corp.

Korea District Heating Corp.

Subtotal $=6$

Restructuring

Agricultural and Fishery Marketing Corp.

Korea Coal Corp.

Korea Highway Corp.

Korea Land Corp.

Korea National Housing Corp.

Korea National Oil Corp.

Korea Resources Corp.

Korea Security Printing and Minting Corp.

Korea National Tourist Org.

Korea Trade and Investment Promotion Agency

Korea Water Resources Corp.

Rural Development Corp.

Korea Appraisal Board

Subtotal = 13 (14 subsidiaries $)$

Total $=24$ (54 subsidiaries $)$
Targeted Subsidiaries of GOCs and GICs

12 subsidiaries, including KT Card Co. and Hanyang Wood Co.

28 subsidiaries, including KT Powertel Co., Korea Liquefied Natural Gas Co., and Korea Power Engineering Co.

Restructuring

6 subsidiaries, including KT Freetel Co. and Korea Nuclear Fuel Co.

Liquidation or merger

8 subsidiaries, including Hanyang Corp. and Korea Real Estate Trust Co.

Source: Ministry of Planning and Budget.

Notes: GOC = government-owned corporation; GIC = government-invested corporation. See table 4.1 for explanation of other abbreviations.

flicting with the other aspect of the Framework Act that is based upon the idea that a GOC is a policy instrument of its line ministry rather than a profit-oriented firm. It is not clear to us how the board, which consists of those outside the government, can make sure that GOCs are run smoothly to achieve the policy objectives of the line ministry.

\section{Regulatory and Industrial Policies}

Not a great deal of changes occurred in the way line ministries go about their business of promoting policy objectives since the privatization began. 
Separation of commercial elements of commercial public enterprises and regulatory functions of the government from the industrial policies of the line ministries in network industries has not even been discussed much. In particular, the regulatory environment for the telecommunications and gas industries has little changed. Further, the communications commission has not been granted independence. The MIC, which also assumes the role of the dominant shareholder of KT, still has the authority to regulate rates and access charges. The market structure and regulatory scheme of the gas industry have not changed much either.

However, there has been a significant change in the policies toward the electricity industry and KEPCO. After two years of study and debates, the government successfully passed the Act for the Restructuring of the Electricity Industry. As a result, KEPCO was split into six generating companies (gencos), a monopolistic firm vertically integrated in the transmission and distribution stages, usually called "post-KEPCO" 33 ; and the pool market. The government also made public its intention to ultimately split postKEPCO into one monopoly for the transmission stage and several local monopolies for the distribution stage.

Finally, a regulatory body - the Electricity Commission - has been established within the line ministry, MOCIE, and was given the authority to regulate the electricity industry. Although the commission is not independent of MOCIE, it was charged with the responsibility to regulate rates. Thus, the Electricity Commission appears, at least on the surface, to be a quite legitimate regulator, unlike the Communications Commission.

The restructuring is still in its early stage. Sales of gencos to a third party independent of post-KEPCO have yet to occur either. Thus, it is too early to tell whether the reform of the electricity industry is a success. It is also too early to tell whether the Electricity Commission, which is only two months old, will perform properly and independently as a regulator.

\section{Recent Developments in Tobacco, Telecom, Oil Pipeline, and District-Heating Industries}

The 1998 privatization plan went through a few changes in the implementation stage. The biggest changes were made with regard to KT\&G and KT, both of which had been classified as public enterprises to be gradually privatized. The government changed its plan and added those two, as well as two other smaller public enterprises (Daehan Pipeline and Korea District Heating) initially classified as those for gradual privatization, to the list of firms to be fully privatized.

The government also made changes aimed at separating industrial policy concerns from the commercial operation of KT\&G. The government

33. The official name of the monopoly is still KEPCO, but many call it "post-KEPCO" to distinguish it from the old monopoly, vertically integrated in all stages of the industry. 
abolished the statutory ban on entry into tobacco manufacturing and is scheduled to open the market in late $2001 .{ }^{34}$ Thus, foreign as well as domestic competitors will be able to compete with KT\&G on more level terms in Korea. At the same time, the government also gave up the right to control the prices of cigarettes produced by KT\&G so that the prices of cigarettes would be determined in the market.

These liberalization measures and privatization of $\mathrm{KT} \& \mathrm{G}$ would undoubtedly have significant impact on the tobacco-growing industry of Korea. $\mathrm{KT} \& \mathrm{G}$ is expected to reduce purchase of tobacco leaves from domestic growers each year until its purchase from domestic growers drops to a certain level. It will also reduce the subsidies that it has given to the association of tobacco-growing farmers for a long time. KT\&G and the association of tobacco growers are currently working on a deal that will require $\mathrm{KT} \& \mathrm{G}$ to make a lump-sum donation to a foundation to compensate for the losses to the association and tobacco growers, resulting from privatization and liberalization of the tobacco industry.

The change in policies toward KT came about as a result of a string of events that few had anticipated. The twist began in 1999 when the government announced its plan to grant three licenses to operate G-3 mobile services, usually called IMT-2000 in Korea, in 2000. The announcement catapulted the five mobile operators, of which four were suffering from losses while the incumbent SK Telecom was earning huge profits, into an intriguing game of mergers and acquisitions played out by competitors in a tight oligopoly. Shinsegi and Hansol ended up offering themselves as merger and acquisition targets. SK Telecom successfully acquired Shinsegi Telecom. Korea Telecom Freetel, a subsidiary of KT, and LG Telecom, affiliated with the LG Group (the fourth largest chaebol group in Korea), competed fiercely to acquire controlling interests of Hansol. Korea Telecom offered more attractive terms than LG and eventually bought 44.1 percent of the shares of Hansol, thus becoming an undisputed second after SK Telecom in the mobile market. ${ }^{35}$

Purchase of controlling interests in Hansol Telecom by KT was probably the first-ever case of a public enterprise voluntarily acquiring a major private firm that was not bankrupt, and thus became the subject of an intense controversy. The criticism directed at KT was that it was not even classified by the government as an enterprise to be privatized and should not be allowed to purchase control of a private operator, as there was a

34. Conditions for a license to operate a manufacturing facility in the tobacco industry are being drawn up.

35 . Becoming the largest and second-largest operators in terms of revenue or, equivalently, the number of subscribers, was considered by many to be a key factor in winning a license for $3 \mathrm{G}$ services at the time. SK Telecom and KT came out as winners in reality. They won the two licenses for users of the asynchronous-mode standard. LG competed with the two for a license for asynchronous-mode standard operators and failed. LG has not won a license yet. 
private suitor willing to purchase Hansol. On the other hand, if the government prohibited KT from making bids on Hansol, it would almost certainly cause serious damage to the competitiveness of $\mathrm{KT}$ and its market value, while at the same time forcing Hansol to sell its shares to LG at less favorable terms. In the end, the government decided to allow KT to go ahead and make a bid on Hansol. At the same time, the government announced that it would completely privatize KT by mid-2002. ${ }^{36}$

Thus, KT is to be privatized earlier than any other large, commercial public enterprise. However, there have not been fundamental changes in the regulatory frameworks or in the way industrial policies are promoted by the line ministry.

\subsubsection{Divestitures and Ownership Distributions}

For all the GOCs except KEPCO, the government is essentially the sole owner. In cases where the government's share is below 100 percent, the shares not owned by the government are owned by other public institutions controlled by the government. The government did not own a single share in Korea Chemical and Korea Heavy in 1997, nor does it now; but these two firms were classified in 1997 as GICs by the government as their dominant shareholders were public institutions that the government could easily control. The government's shares in POSCO, KTB, and Korea Textbook were reduced to zero between 1997 and 2000. KTB and Korea Textbook have been completely privatized. However, POSCO is not generally viewed as a fully privatized company because its largest shareholder is the Industrial Bank of Korea, which is a public enterprise controlled by the government.

Table 4.6 summarizes the ownership distributions for the Big Six as of December 2000. KEPCO is still 52.2 percent owned by the government. Of the remaining shares, 26 percent are owned by foreign investors. Further dilution of the government's share is not likely to occur for a while because most of the loans that KEPCO borrowed from foreign creditors have a condition in the loan contracts that allows the creditors to call for early payments if the government's share falls below 50 percent. There is no major investor other than the government.

The government's share in KT is 59 percent. However, it will drop to less than 30 percent if the current efforts by the government to sell additional shares to foreign investors succeed. The government is also planning to sell off the remaining shares by 2002. Kookmin Pension, the largest pension in Korea, is the second largest shareholder after the government. The remaining shares are owned by a few financial institutions as well as many small investors. Foreign ownership stands at 19.4 percent.

36. The discussions above suggest that $\mathrm{KT}$ was already an operator that was as commercial in nature as any others in the telecom business were. The government may have simply ignored this obvious fact until it was too awkward to continue to ignore it. 
Table 4.6

\begin{tabular}{|c|c|}
\hline Company & Main Stockholders \\
\hline KOGAS & $\begin{array}{l}\text { Korean government: } 26.9 \% \\
\text { KEPCO: } 24.5 \% \\
\text { Local government: } 9.8 \% \\
\text { Daeshin Securities: } 7.2 \% \\
\text { Foreigners: } 2.1 \%\end{array}$ \\
\hline KT\&G & $\begin{array}{l}\text { Korean government: } 13.8 \% \\
\text { Industrial Bank of Korea: } 35.2 \% \\
\text { The Export-Import Bank of Korea: } 7.0 \% \\
\text { Daehan Investment Trust: } 7.0 \% \\
\text { Foreigners: } 5.0 \%\end{array}$ \\
\hline POSCO & $\begin{array}{l}\text { Industrial Bank of Korea: } 4.9 \% \\
\text { Foreigners: } 48.6 \%\end{array}$ \\
\hline $\mathrm{KT}$ & $\begin{array}{l}\text { Korean Government: } 59.0 \% \\
\text { Foreigners: } 19.4 \%\end{array}$ \\
\hline KEPCO & $\begin{array}{l}\text { Korean Government: } 52.2 \% \\
\text { Korea Deposit Insurance Corp.: } 5.1 \% \\
\text { Foreigners: } 26.0 \%\end{array}$ \\
\hline $\begin{array}{l}\text { Korea Heavy Industries and Construction } \\
\text { Co., Ltd. (Doosan Heavy Industries and } \\
\text { Construction Co., Ltd.) }\end{array}$ & $\begin{array}{l}\text { Doosan Corp.: } 36.0 \% \\
\text { Korea Development Bank: } 12.6 \% \\
\text { KEPCO: } 11.7 \%\end{array}$ \\
\hline
\end{tabular}

Source: National Information and Credit Evaluation.

Note: See table 4.1 for explanation of abbreviations.

\section{Korea Tobacco and Ginseng}

The government's share in KT\&G was close to 100 percent before the onset of the crisis. Its ownership kept decreasing after the onset of the economic crisis to the current level of 13.8 percent, as a result of a series of government investments in several banks using the KT\&G shares. The purpose of the investments was to increase the size of the equities as well as the Bank for International Settlements ratios of the banks and other financial institutions, which were necessary from the perspective of financial and corporate restructuring. The banks that own KT\&G shares were not expected to actively exercise their rights as major shareholders, and the government can still control 53 percent of the shares. Small investors and various financial institutions own around 15 percent.

\section{Pohang Steel Company}

The government sold its remaining 3 percent in 2000 and currently does not own a single share in POSCO. But it is believed to be able to control POSCO through its influence over the Industrial Bank of Korea, which is the largest single shareholder with 4.9 percent. It is not clear at this point 
whether the corporate governance of POSCO will remain as it is or whether a chaebol would be allowed to take control. POSCO has not been subject to the Special Act.

\section{Korea Gas Corporation}

KOGAS used to be owned by the government, KEPCO, and various local governments, which initially owned $50.2,35.5$, and 14.3 percent, respectively. KOGAS became listed after a public offering in which 38.8 percent was sold to institutional investors and small investors. ${ }^{37}$ The shares held by the government, KEPCO, and local governments were reduced to $26.8,24.4$, and 9.8 percent, respectively, as a result of the offering. KOGAS is still controlled by the government.

\section{Korea Electric Power Corporation}

The Korean government owned more than 70 percent of the shares of KEPCO until 1996. An additional sale of KEPCO shares in 1998 lowered the government's share to 58.2 percent, while it increased the shares held by general investors to 36.4 percent. The government sold an additional 5 percent of depository receipts (DRs) for US\$750,000,000 in 1999, further reducing its share to 53.2 percent. The shares held by foreign investors were a meager 1.14 percent in 1992, but increased to 10.99 percent in 1995 and 26.11 percent in 2000 .

\section{Korea Heavy}

Korea Heavy used to be owned by KEPCO, Korea Development Bank, and Korea Exchange Bank, with 40.5, 43.8, and 15.7 percent, respectively. The government fully controlled Korea Heavy using its dominant position in all of the three public enterprises. In 2000, the government forced KEPCO and Korea Development Bank to sell 28.8 percent and 31.2 percent, respectively, of Korea Heavy (a total of 60 percent of the outstanding shares) to a chaebol consortium, the employees' ownership program, and the general investors. Doosan Group purchased 36 percent, while the Employee Ownership Plan (EOP) and the general investors purchased 10 percent and 14 percent, respectively. Doosan appears to be in a position to wield control of Korea Heavy.

\section{Korea Telecom}

Divestiture of KT started in 1993. During the 1993-1996 period, the government attempted to sell 49 percent of KT shares, but were able to sell only 28.8 percent for 2.751 trillion Korean won to domestic investors. In

37. Daeshin Securities ended up owning 7.2 percent of KOGAS since it was the main broker in the last public offering of KOGAS and had an obligation to maintain the share price above a certain level. 
1999, the government sold 14.4 percent to foreign investors through issuing DRs that were listed on the New York Stock Exchange and London Stock Exchange and reduced its shares from 71.2 percent to 56.8 percent. ${ }^{38}$ The sales brought in US $\$ 2.48566$ billion, of which US $\$ 1.14723$ billion went into the government coffer. Another effort at selling additional shares domestically early in 2001 was unsuccessful. As of July 2001, the government was trying to sell up to 15 percent of shares to a foreign strategic investor and an additional 17.8 percent to investors in the international market through issuing DRs. The government sold the remaining shares to private investors in 2002.

The largest shareholder after the government is Kukmin Pension, with 3 percent. No other shareholder owns more than 1 percent. There are two restrictions on the ownership of KT shares in addition to the 15 percent ceiling for any single party. First, the Telecommunications Industry Act puts a ceiling on the combined ownership in KT by foreign investors at 49 percent. Second, the act also forbids a foreigner to become the largest shareholder of KT. The last restriction on the ownership of KT was introduced to maintain KT as a Korean firm. But no such restriction exists for SK Telecom or any other telecom operator in Korea.

\section{Other, Smaller Public Enterprises}

Of the smaller GOCs and GICs, four relatively small GICs have been completely privatized since the privatization drive of the current administration began in early 1998. All of the government's shares of KTB and Korea Textbook have been sold to a venture capital and a private textbook company, respectively. Korea Chemical was not sold as a whole. Instead, the government forced Korea Chemical to sell its major business unit, Namhae Chemical, which was also the only unit within Korea Chemical that had any economic value, to Farmers' Association (Nonghyup).$^{39}$ Daehan Pipeline has also been sold to a consortium of investors headed by the SK Group, which has a refinery and oil distribution subsidiary.

The results of the new administration's privatization program are far more extensive and thorough compared with those of preceding administrations. However, the privatization process is far from complete and is still unfolding. Large public enterprises are not fully privatized. Although a few small public enterprises are fully privatized, they have been in private hands for less than three years. Thus, it is not possible to conduct a meaningful evaluation of the effects of privatization in Korea, similar to the one offered by Galal et al. (1994).

38. Of the 14.4 percent, 6.7 percent were old shares, while the remaining 7.7 percent were newly issued ones.

39. There is the question of whether this was a bona fide privatization. Farmers' Association is a nonprofit organization and is considered by many to be no better than other public enterprises in terms of efficiency. 


\subsection{Other Government Involvement in Commercial Activities and in the Financial Market}

The public enterprises that we have covered thus far in this paper comprise only a fraction of the larger set of commercial organizations that are owned and controlled by the government. The government fully owns and runs the postal service and rail transportation as government agencies. The postal service is a part of the MIC organization. Korea Rail, the monopoly in the rail and rail transportation industry, is an agency within the Ministry of Construction and Transportation. Local governments have set up a large number of local public enterprises. The best known example is City Rail of Seoul, which continually posted large losses.

The area in which the government's ownership and control is the most crucial, but has been neglected in this paper, is the financial sector. The government has been the dominant player in the financial sector over the past four decades, frequently allocating financial resources to the projects that it favored. The government actually owned and directly controlled many financial institutions, including several banks and their subsidiaries, even before the economic crisis hit Korea in 1997. The government had a controlling interest in Korea Development Bank, Korea Housing Bank, Kookmin Bank, and Industrial Bank of Korea. It utilized these banks and their subsidiaries as instruments for its policies toward the financial market.

The government also was somehow able to wield tight control over the banks in which it had no or few shares. Most of the commercial banks and their subsidiaries had been tightly controlled by the government, despite the fact that chaebols were the largest shareholders of the banks prior to the onset of the economic crisis. ${ }^{40}$ It is worth noting that although chaebols owned a large share of banks, they were not allowed to wield control of the banks. However, the chaebols ended up being able to obtain large amounts of loans from the banks anyway, as they were aided by government that intervened in the management of the banks. It was revealed later on that a large proportion of the loans made to many chaebols this way turned out to be lost in unprofitable projects. The result was the massive bankruptcies of large firms, which immediately translated into deep financial difficulty of many banks and financial companies. Roughly one-third of the chaebol firms became insolvent or fell in deep financial trouble since 1997.41

Many banks and nonbank financial institutions have been closed since

40. There was a 5 percent ceiling on the individual ownership of commercial banks before the onset of the crisis. Major chaebol, such as Samsung or Hyundai, owned large shares of the banks while meeting the 5 percent constraint. The government somehow succeeded in preventing large shareholders from participating in the governance of the banks, taking on the role itself.

41. The list of casualties includes such well-known names as Hanbo, Kia, Dong A Construction, Halla, Jinro, and many Daewoo firms (including Daewoo Motors and Daewoo Corporation). Recently, Hyundai Construction was also added to this list. 
1998. Most of those that survived had to be recapitalized by the government's money and ended up being mostly owned by the government. Thus, much of the financial sector has been nationalized, while parts of the corporate sector dominated by public enterprises have been privatized. Further, most of the large chaebol firms that went bankrupt or fell into serious financial trouble ended up being owned by the banks or placed in court receivership. Large firms in which the banks became major shareholders suffer from the absence of a proper governance mechanism, as the banks themselves are not equipped with a well-functioning governance mechanism.

Firms in court receivership are basically governed by the judges and run by trustees who are appointed by the judges. While judges in Korea are generally trustworthy and competent in enforcing laws, they are not businessmen and have little incentive, other than their sense of responsibility to society, to try to make the firms commercially successful. Trustees also appear to face an incentive structure that often leads them to enjoy the perks of a chief executive officer rather than to try to turn the firms around and sell them to prospective investors. Firms in court receivership sometimes appear to be another breed of public enterprise that lacks a proper corporate governance structure based upon well-defined profit motives.

The banks and other financial institutions that have been nationalized, as well as the bankrupt firms that are in court receivership or are controlled by creditor institutions, need to be recognized as public enterprises that should be privatized. Thus far, the government has privatized only First National Bank, which essentially became nationalized after going through bankruptcy and recapitalization with the government's money. In addition, a sizable proportion of shares of some banks, including Kookmin Bank, was sold to foreign investors. However, it will take quite a while to completely privatize the banks and establish a well-functioning system of financial regulation. Privatization of the firms in court receivership or in workout programs is not an easy task, either.

\subsection{Concluding Remarks}

Korea has made significant progress in privatizing the commercial businesses owned by the government. Korea's approach to commercial public enterprises and their privatization differs, in several respects, from that of New Zealand and the United Kingdom or other European countries that are going through large-scale privatization. In those countries, the government separated the policy concerns from the public enterprises to be privatized. However, that was not the case in Korea. Rather, privatization policies were mostly focused on divestiture and often lacked concrete plans on a broader set of issues concerning industrial organization of the relevant markets and the policies thereupon. 
In network industries, privatization policies focused on partial sales of the shares owned by the government and did not pay much attention to the industry structure, competition policies, or regulatory frameworks. The policy environment was, by and large, left intact, as were the functions and organizations of the line ministries. These differences are probably due to the way the government is organized and operates in Korea. Line ministries of commercial public enterprises in Korea have long been granted the authority to intervene in the relevant industries to promote a wide range of policy objectives. Separation among commercial operation of the public enterprises to be privatized, regulatory functions of the government, and the industrial policies of the government probably require a fundamental change in the way the line ministries operate, and more generally in the way the government is organized and operates. It appears that Korea was not ready to make such a change in the way the government is organized and operates with regard to privatization.

Another crucial factor that affected the privatization path of Korea is the absence of a properly functioning financial market and adequate corporate governance systems for large firms. Extensive reliance on the chaebol system and the accompanying heavy government intervention in the financial market during the past four decades deprived the financial sector of a fair chance of developing into a well-functioning market. The only governance systems that existed in Korea for large firms were essentially ownership and control by the government or control by chaebol families that depended crucially upon heavy government intervention in the financial market.

In fact, the chaebol system can be viewed as a device that uses a handful of families as artificial corporate-governance agents. Key chaebol firms were established with the money borrowed from banks as a result of intervention by the government in the banking sector. Thus, it was eventually the government and not the chaebol families who took the risks in investing key chaebol firms. Actually, it turned out after the onset of the economic crisis that the government indeed covered the losses of the banks and the chaebol firms when chaebol firms went bankrupt.

It would be unrealistic to expect the chaebol system, which is based on a government-controlled financial sector and lack of transparency and accountability, to produce an efficient outcome. In fact, section 4.3 showed that chaebol firms performed quite poorly. It seems quite clear that the chaebol system is not a plausible alternative for privatizing large SOEs in Korea. In fact, chaebol firms, which are already heavily leveraged, do not have enough money to purchase controlling interests in large SOEs. The only way to sell SOEs to chaebols would be by lending them money and letting them play the role of artificial corporate-governance agents. This is actually the way chaebol families obtained control of the firms under their control now. 
A more proper mode of privatization needs to be developed. Developing a new mode of privatization requires establishing a new mode of corporate governance in large firms and financial institutions in Korea. Korea has yet to come up with a model of corporate governance for large, commercial firms that can be relied upon by a majority of investors. For this to occur, the financial market must be made to work based upon sound profit incentives of banks and other financial companies as well as effective prudential supervision.

The financial market in Korea is going through a fundamental change after the recent economic crisis, which was caused at least in part by the lack of proper governance systems in large firms and financial institutions. Korea's chance of successful privatization crucially depends on whether and how fast it can turn around its financial market, which in turn demands the adoption of a stable and efficient governance model by large corporations in the real as well as financial sectors.

\section{References}

Galal, Ahmed, Leroy Jones, Pankaj Tandon, and Ingo Vogelsang. 1994. Welfare consequences of selling public enterprises: An empirical analysis. New York: Oxford University Press.

Nam, Il Chong, and Yung Jae Kang. 1998. Privatization strategy (in Korean). KDI Journal of Economic Policy 20 (3-4): 111-165.

Nam, Il Chong, Yung Jae Kang, and Joon Kyung Kim. 2001. Corporate governance trends in Asia. In Corporate governance in Asia: A comparative perspective, ed. Stilson Nestor and Takahiro Yasui, 85-115. Paris: Organization for Economic Cooperation and Development.

Nam, Il Chong, Yung Jae Kang, Joon Kyung Kim, Jun Il Kim, and Sung Wook Cho. 2001. Corporate governance in Korea. In Corporate governance in Asia: A comparative perspective, ed. Stilson Nestor and Takahiro Yasui, 155-216. Paris: Organization for Economic Cooperation and Development.

\section{Comment Cassey Lee Hong Kim}

Nam's ambitious survey paper succeeds in discussing the different types of public enterprises that exist in South Korea and the reforms that these entities have undergone in the past four years. I will confine my comments to the reform process because the paper raises several interesting questions in this area. The most obvious one has to do with the question of why South

Cassey Lee Hong Kim is head of the department of applied economics at the University of Malaya. 
Korea took so long to implement economic reforms in the public enterprise sector. Compared to other countries, South Korea is a relative latecomer to the economic reform scene. While many countries have embarked on privatization programs since the early 1980s, South Korea only began privatizing its public enterprises in 1997.

The first question brings us to a second related question: that is, what were the main driving forces underlying these reforms? There is some evidence that efficiency gain was an important motivating factor. For example, one piece of legislation that made reforms possible in 1997 was an act that had the revealing title the "Act for Privatization and Improvement of the Efficiency of Large Public Enterprises" (or the Special Act on Privatization). But it is hard to believe that efficiency gains alone could convince politicians to undertake reforms. Economic reforms of public enterprises require tremendous political willpower for the simple reason that they generate significant public concern. In the case of some countries, economic reforms could take place only with the emergence of strong new political leadership, as was the case with Britain (under Thatcher) and Malaysia (under Mahathir). In the case of South Korea, were there any changes in its political regime that made possible these reforms of its public enterprises? ${ }^{1}$

The author identifies two waves of reform of public enterprises in South Korea. Each episode of reform was undertaken by a new political administration. The first wave began in 1994 when the government commissioned a study of several public enterprises. This culminated in the passage of the Special Act on Privatization in 1997. The seed for the first wave of reform was planted as far back as 1993, when Kim Young Sam became the first democratically elected civilian president since the military coup d'etat of 1961. Kim Young Sam rode in on a reform ticket during the election and, a month after coming to power, the newly elected president unveiled two reform packages: the One Hundred-Day New Economy Plan and the FiveYear Plan for the New Economy. Even though these plans did not recommend privatization of public enterprises, they inevitably led to it, because the central motto of both plans was "small government" and "respect for the private sector's creativity and vitality."

How successful was the first wave of reform? The main objective of the first wave was to transform a few selected public enterprises into profitoriented firms with good (read: Anglo-Saxon) governance structure. Even though Nam's paper does not explicitly take a stand on this issue, one gets the distinct feeling that the reforms were of limited success on several accounts: public policy continued to exert influence in the selected firms; too few firms were involved; and no regulatory reforms were carried out. In the

1. One would think politics assume an even greater role in countries with strong workers' representation (unions). 
paper, Nam does mention two major constraints to reforms: the desire to exclude chaebol participation and limited equity-acquisition capacity of domestic investors. Aside from this, one is left to wonder about the bureaucratic and political constraints as well.

By 1997, the political support for the Kim administration began to unravel with industrial unrest, economic crisis, and political scandals. This culminated in South Korea's seeking an emergency loan package of US\$21 billion from the International Monetary Fund (IMF) in November 1997. It is under this scenario that the veteran opposition leader Kim Dae Jung won the December 1997 election. Thus, the second wave of reforms that began in 1998 was undertaken under a very different environment - a new political administration, economic crisis, and the IMF. I think it would be interesting to know how each of these factors influenced the extent and speed of reforms of public enterprises after 1998. For example, was privatization an issue on Kim Dae Jung's election agenda? Was privatization perceived as having a role to play in the resolution of the economic crisis? Did the reforms demanded by the IMF agreement include reform of public enterprises? ${ }^{2}$ On the last question, there is some evidence that suggests that privatization in the immediate aftermath of the economic crisis in 1997 was not affected by the standby agreement between the South Korean government and the IMF. A perusal of the letter of intent that the South Korean government sent to the IMF, dated 7 February 1997, shows that it concentrated on issues such as macropolicies, financial restructuring, capital account liberalization, trade liberalization, labor market reform, and corporate governance reforms. ${ }^{3}$

The second wave of reform remains unfinished. But in the three years since its commencement, the privatization record has been a mixed one. Nam's paper shows that the divestitures carried out were not sufficiently extensive to reduce the government's ability to intervene in companies. Nam points out that the limited success of recent reforms arises from not having paid attention to issues pertaining to industry structure, competition policies, and regulatory frameworks. But looking at Korea's development experience, one would imagine that an extensive change in a short time would not have been possible without tearing apart the country's social and economic fabric.

Many of the economic problems that South Korea faces today are a legacy of a very comprehensive and consistent implementation of a stateled industrialization policy for at least three decades (since the 1960s). The government essentially took control and harnessed the resources of both

2. It was reported in the media that the IMF had actually demanded that all the three major candidates in the 1997 election pledge support for terms in the IMF agreement to be signed.

3. Privatization initiatives only appeared later in the letters of intent to the IMF in March and November 1999. 
the financial sector and public enterprises to support the development of large conglomerates (chaebols). In Nam's paper, it is evident that chaebols remain an important factor even when we discuss the reforms of public enterprises. Because they have such a strong presence in the economy it is difficult to see how they can be excluded unless a long-term policy of reducing their role in the Korean economy is undertaken. For example, if further reforms of public enterprises require a move away from a bank-based to a financial-market-based financial system, then parallel changes in corporate finance will be required. But such changes are far from easy to carry out. South Korea's recent experience is an example. It appears that during the first wave of reform (1994-1997), the chaebols were excluded from participating in the reforms of public enterprises partly on account of their dismal track record and their involvement in political scandals in the previous political regimes. But after this period, it is possible that politicians and policymakers have increasingly realized that these entities are too important to exclude unless one can muster enough sustainable political support to alter the role of chaebols in the Korean economy. Recent developments, such as relaxation of the ownership limit on chaebols in financial institutions, seem to indicate this to be the case. Hence, chaebol reform lies at the heart of successful reforms in both the financial system and the public-enterprise sector. All this will depend on the emergence of a political environment that is supportive of the implementation of extensive reforms that incurs the risk of de-industrialization and reduced competitiveness. 